\title{
The Compliance of Ecological Design on Public Buildings on the University Campus Environment in Malaysia
}

\author{
M. Zainora Asmawi and Abdul Razak Abd Aziz
}

\begin{abstract}
The concern for the natural and built environment has become crucial in relation to the concept of sustainable development. Literatures show that the ecological design (ED) concept has produced positive results in supporting the achievement of sustainable development, though it faces many challenges amongst public and other stakeholders of its importance towards a green environment. This research attempts to seek the level of the ED compliance in the Putra University of Malaysia campus. The objectives are: (1) to determine the present ED features that are being practised in education building in the campus; and (2) to identify the level of compliance of $E D$ variables in the campus. An observation survey of 23 selected buildings within the campus was conducted, based on a set of pre-determined five variables and its sub-variables in determining the level of compliance to ED. The results demonstrated that the level was relatively moderate, and many buildings failed to comply with some variables of ED. It is concluded that the research has met its outlined objectives in which the findings demonstrate that the level of $\mathrm{ED}$ compliance in the campus can be considered as moderate.
\end{abstract}

Index Terms-Ecological design, university campus, Selangor, sustainable development.

\section{INTRODUCTION}

Planning and designing with careful attention for the environment is a key element in the architecture field, though architects are not steadily setting themselves as champions in environmental design or sustainability research [1]. History shows that the pursuit of environmental value in architecture, for a harmonious balance between man and his surroundings is not new. One of the most momentous current discussions in environmental architecture is sustainable architecture. Environmental quality could bring together human convenience and comfort, sustainable use of natural resources and materials. As such, applied to architecture discipline, the awareness of sustainable architecture requires the integration of construction business and materials, along with a shift in attitudes on the part of both professional and public generally [2]. In Malaysia, currently the level of awareness of sustainable development in the field of construction activity is relatively low [3]. Many key players and stakeholders, namely consultants, builders, developers, manufacturers and government are lacking the positive attitude towards the green effort. Very current movement in ecological design (ED) in Malaysia is the setting up with a rating system known as

Manuscript received July 1, 2014; revised November 26, 2014.

M. Z. Asmawi is with the International Islamic University, Malaysia (e-mail: zainora@ iium.edu.my).

A. R. A. Aziz is with Saujana Rekabina, Malaysia (e-mail: ajakaziz@gmail.com).
Green Building Index (GBI). In the light of growing concern of sustainable architecture, this study attempts to identify the level of applying the approach of ED in a university setting, i.e. Putra University of Malaysia, Serdang campus. The environmental approach is an innovative approach to building issues, including the project design, construction and building management. In this regard, the notion of ED is essential in addressing the importance of architecture toward better environmental quality as a whole. Thus, the research objectives of the study are to: (1) to determine the present ED features that are being practised in education building in the campus; and (2) to identify the level of compliance of ED variables in creating a sustainable campus environment.

Problem statements identified in this research are:

- The using of building materials increases the heating of the surrounding area because of lack of application of more environmental-friendly approach in the local education buildings has contributed many environmental problems, such as urban heat island.

- The natural surrounding environment which conducive for the students was decreased because of the current practice of education buildings demonstrates that it uses buildings design that reduces the environmental quality. Hence, the practitioners in the building industry need to change their practices for the betterment of the environment as a whole.

- The recognition of ED approach is very low in Malaysia that needs more attention if we want to support sustainable development. The awareness of the importance of protecting the environment regardless the type of professions is very low in the Malaysian context.

\section{LITERATURE REVIEW}

Ecological design (ED) or eco-design relates very much to the natural and built environment. Reference [4] defines ED as "any form of design that minimises environmentally destructive impacts by integrating itself with living processes". This definition emphasises on using design to lessen or minimise environmental impact on the whole system of environment. There are many terms of ED, that carry the same connotation. The term ED is also referred to as 'green architecture', 'green design', 'alternative architecture', 'sustainable architecture', natural architecture', 'environmental architecture', and 'sustainable design' used to describe a special expression of design that takes as its primary driving force nature's processes [5]-[8]. It is an approach to building construction that minimises negative effects on human wellbeing and the natural environment. ED is about the use of ED principles and strategies to design the 
built environment. It is an approach to introduce the relation of the component, in the environment to the design. The input of the component ED included biosphere, ecosystem, air, land and water. ED strategies and principles are integrated with the natural environment which containing in the biosphere. It is important to integrate the natural environment with the building design in order to preserve the quality of the natural environment since some part of the area taken by the building. The relevance of building forms, spatial organisation and the internal and external properties of the building envelope are the means by which architectural work process can meet the notion of ED. Reference [9] indicates that the related variable had been studied either empirically and analytically, the dynamic aspects of building performance and the resulting interactions between the occupants, buildings and engineering appliances, are still poorly understood and largely unexplored architecturally.

ED in the built environment is about the form of design of ED that can be applied in various disciplines, ranging from architecture, landscape architecture, urban planning, urban design, engineering and others. It means that the application of ED depends on the scope of the field as long it contributes towards a better environmental quality. In discussing the ED, it cannot escape from concerning with development and planning in that matter. Therefore, the concern on ED should be observed in relation to design process aspect since it relates very much to the development process within its context. In the built environment, ED is important as it is considered as an element in the entire integrated design process and not only acts as an attachment or a supplement component of the design team. Meaning that the application of ED requires close cooperation and coordination of the design team, consisting many professions, such as the architects, the engineers and urban planners.

\section{MATERIALS AND METHODOLOGY}

This research employed descriptive and argumentative analysis to explain the assessment of the practice of ED in Malaysian experience. It combined qualitative and quantitative approaches and used commonly employed techniques to address research topics in applied social science. Two research methods were used in data collection; they are literature review, analysis and site observation involving 23 buildings (depending on the checklist format for each building). Literature review analysis based on relevant documents involved deconstructing secondary data that supports the primary data. This research used working documents from the fields of architectural design as evidential materials. It played an important role as it provided background information that established a link with the analysis stage. A wide range of documents such as reports, plans, and articles journals related to ED were referred to. The site observation technique allowed in-depth analysis of the complicated existing systems for Ed and of their interconnectivity with the overall built environment. In this research, a set of pre-determined variables and its sub-variables have been used to assess the level of compliance of the selected buildings. Data collected were analysed using a set of simple pre-determined ED factors used in the site observation survey. Based on several models available on the rating system applied elsewhere in the world, the researchers developed an observation checklist to get the status of ED of a building. A common set of value, starting with 3 (very significant), 2 (moderate significant), 1 (minor significant) and 0 (not applicable) was developed. The total earn point was then divided into three categories of compliance level to the ED concept, i.e. highly responding (73-108 points), moderately responding (37-72 points) and poorly responding (less than 36) (Table I). This division of marks developed the rating system for this particular small research of selected buildings in UPM Serdang campus.

\begin{tabular}{|c|c|c|c|c|c|c|}
\hline & 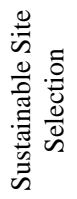 & 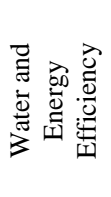 & 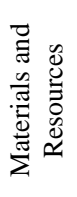 & 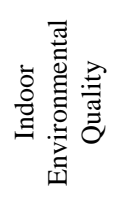 & 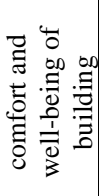 & 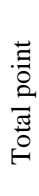 \\
\hline $\begin{array}{l}\text { No. of } \\
\text { elements }\end{array}$ & 11 & 7 & 4 & 6 & 8 & 36 \\
\hline $\begin{array}{l}\text { Highest } \\
\text { rank }\end{array}$ & 3 & 3 & 3 & 3 & 3 & - \\
\hline $\begin{array}{l}\text { Highest } \\
\text { point } \\
\text { earned }\end{array}$ & 33 & 21 & 12 & 18 & 24 & $\begin{array}{c}10 \\
8\end{array}$ \\
\hline
\end{tabular}

In the site observation study, the researchers assessed the application of methods or approach that respond to the notion of sustainable design, using a series of checklist of variables without prioritising their level. The point system used in the study enables the consistency of format of analysis in this research (Table II).

TABLE II: CLASSIFICATION OF ED IN PUTRA UNIVERSITY OF MALAYSIA,

\begin{tabular}{|c|l|}
\hline Weightage & \multicolumn{1}{c|}{ SERDANG CAMPUS } \\
\hline$<36$ points & $\begin{array}{l}\text { Respond poorly to the ED concept in which the } \\
\text { construction does not employ the principles of ED }\end{array}$ \\
\hline $\begin{array}{c}37-72 \\
\text { points }\end{array}$ & $\begin{array}{l}\text { Respond moderately to the ED concept in which the } \\
\text { construction employs some parts of the principles of ED }\end{array}$ \\
\hline $\begin{array}{c}73-108 \\
\text { points }\end{array}$ & $\begin{array}{l}\text { Respond significantly to the ED concept in which the } \\
\text { construction employs many principles of ED }\end{array}$ \\
\hline
\end{tabular}

The system of weighted for this study looks into a few models available internationally, such as the system of Leadership of Energy and Efficient Design (LEED) in the USA, Greenmark in Singapore and many others. As the scale of this research is small, the researcher has to scale down the list of elements of ecological design to suit the local needs, particularly in the construction of buildings in UPM Serdang campus.

\section{RESULTS AND DISCUSSION}

\section{A. Overall Results According to Faculty Building}

From the assessment of the 23 buildings in Putra University of Malaysia campus, the overall results show that the Centre of Information Development and Communication has the lowest point (35 points) and the highest point was 66, earned by the Faculty of Educational Studies (Fig. 1). There are several buildings corresponded fairly well. Current scenario 
shows that the average point for the selected 23 buildings is 49 , considering that the buildings responded moderately to the ED concept in which the buildings employed some parts of the principles of ED. The construction period for these buildings were at early 1980s until 1990s in which at that time, the activity did not consider the environmental approach in the designing and constructing buildings. However, the building of the Faculty of Educational Studies demonstrated that some parts of the principles of ED had been gradually applied in its design. For instance, the factor of materials and resources gave impact of the result of the faculty. Analysis done based on the observation and supported by the secondary data demonstrates that the overall construction of faculty buildings in the Putra University of Malaysia, Serdang campus complied with the concept of ED can be considered as moderate level. The newer buildings responded rather satisfactorily to the concept of ED compared to the older buildings (Fig. 2).

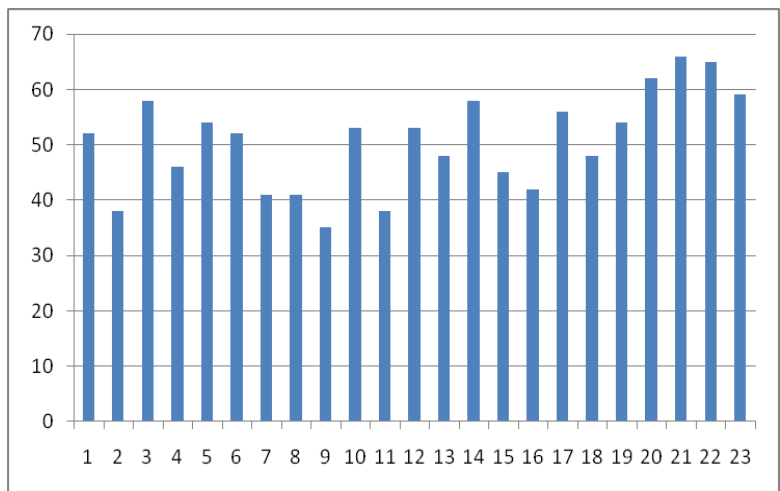

Fig. 1. Overall result according to faculty buildings.

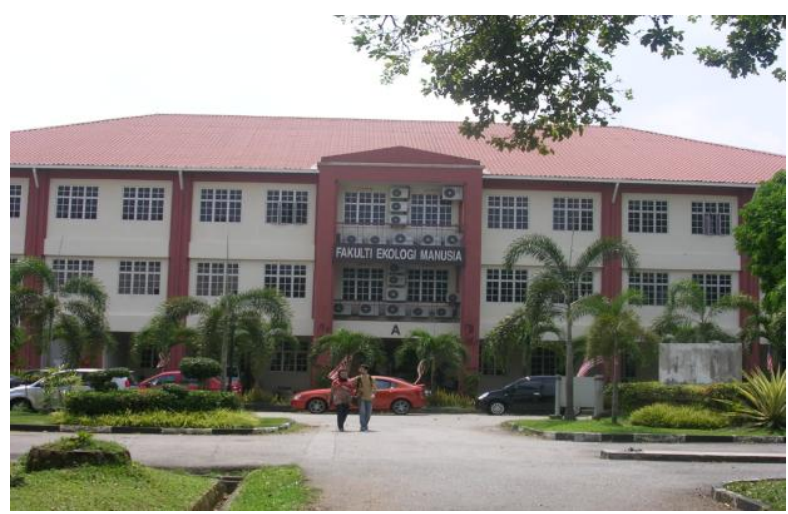

Fig. 2. The faculty of human ecology earned good point for the factor of water and energy efficiency.

\section{B. Overall Results According to the Factors of ED}

The overall results show that based on the selected faculty buildings in which it indicates that the factor of indoor environmental quality has the highest point earned, i.e. 14.3 as compared to the desired point, i.e. 18, which make it achieved $79.4 \%$ of that particular factor (Table III). This demonstrates that the UPM management has been applied the building technology in its design in which it reflects the compliance of ecological design concept. The elements of indoor environmental quality that have been practised were installing the smoke control system, and applying environmentally-friendly substances in the construction materials, such as paints.
TABLE III: OVERALL RESULTS ACCORDING TO FACTORS

\begin{tabular}{|c|c|c|c|c|c|c|}
\hline Factor & 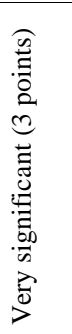 & 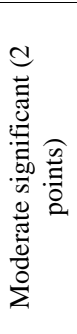 & 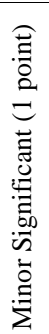 & 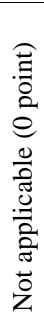 & 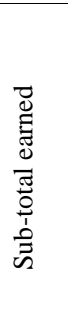 & 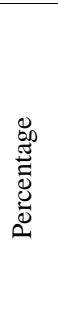 \\
\hline $\begin{array}{l}\text { Sustainable } \\
\text { Site Selection }\end{array}$ & 16.8 & 2.5 & 1.2 & 0 & 20.5 & 62.1 \\
\hline $\begin{array}{l}\text { Water and } \\
\text { Energy } \\
\text { Efficiency }\end{array}$ & 2.3 & 0.3 & 0.2 & 0 & 2.8 & 13.3 \\
\hline $\begin{array}{l}\text { Materials and } \\
\text { Resources }\end{array}$ & 0.3 & 1.4 & 0.2 & 0 & 1.9 & 15.8 \\
\hline $\begin{array}{l}\text { Indoor } \\
\text { Environmenta } \\
1 \text { Quality }\end{array}$ & 12.8 & 1.0 & 0.5 & 0 & 14.3 & 79.4 \\
\hline $\begin{array}{l}\text { Productivity, } \\
\text { comfort and } \\
\text { well-being of } \\
\text { building } \\
\text { occupants. }\end{array}$ & 5.7 & 3.7 & 1.5 & 0 & 10.9 & 45.4 \\
\hline TOTAL & 37.9 & 8.9 & 3.6 & 0 & 50.9 & 47.1 \\
\hline
\end{tabular}

The lowest response to the concept of ecological design is the factor of water and energy efficiency that is only $13.3 \%$ of the achievable target. As this factor requires advanced high-technology in the building materials and construction method, it would lead to big investment and this action is costly. At this point, the administration of UPM does not consider it as a significant effort in supporting the notion of ecological design. Generally, the overall results indicate that the level of compliance to the concept of ecological design at UPM Serdang campus is relatively encouraging as it has $47.1 \%$ of the total desired points. This can be considered as a good start as it needs many involvements of stakeholders in making it a reality to fully commit to the ecological design in the campus area. The areas that require attention and action are water and energy efficiency and materials and resources in the building design and operation.

\begin{tabular}{|c|c|}
\hline Sub-factor of Sustainable Site Selection & $\begin{array}{l}\text { Total } \\
\text { desired } \\
\text { point }\end{array}$ \\
\hline 1. Control site erosion. & \multirow{11}{*}{33} \\
\hline $\begin{array}{l}\text { 2. Avoid inappropriate development sites and } \\
\text { reduce the environmental impact from the } \\
\text { location of a building. }\end{array}$ & \\
\hline 3. Public transportation access. & \\
\hline 4. Alternative transportation bicycle use. & \\
\hline 5. Alternative transportation parking capacity. & \\
\hline 6. Maximise open space. & \\
\hline 7. Stormwater design quantity control. & \\
\hline 8. Stormwater design quality control. & \\
\hline 9. Heat island effect non-roof. & \\
\hline 10. Heat island effect roof. & \\
\hline 11. Light pollution reduction. & \\
\hline
\end{tabular}

\section{Factor of Sustainable Site Selection}

Site selection is very essential in determining the location of the building. In doing so, there are a few influential elements that need to be taken into account when the location of a site is in the process of selection (Table IV). In terms of 
this factor, four buildings obtained points of more than 25 which is fairly close to the desired point of 33: the Faculty of Forestry; Faculty of Agriculture; Faculty of Human Ecology (Department of Resource Management and Consumer Studies); and Faculty of Educational Studies. The Faculty of Mathematics had the lowest point (13). This is due to its failure to observe the user and environmentally friendly approach. For instance, the very minor application had been applied in ensuring that the aspect of site selection is well taken care of in designing that faculty.

\section{Factor of Water and Energy Efficiency}

The purpose or water and energy efficiency is to be used as a measurement of the consumption of water and energy supply of the building. This is essential as it would affect the management cost of the building. The smart choice of technology used in constructing buildings will definitely benefit many aspects such as financial and environmental quality. Table $\mathrm{V}$ shows the pre-determined set of elements that were taken into account under the factor of water and energy efficiency. Some parts of them have been employed in the Malaysian context, though it is not many, such as using water efficiently for landscaping purposes. As this factor held the lowest mark, the implementation of it is very weak and some may not apply at all. In order for the UPM management to adopt this smart technology, they need to invest in this effort to produce smart buildings that respond positively to the idea of ecological design. There were three buildings which low in responding to this factor: Centre of Agriculture Science; Centre of Information Development and Communication; and Faculty of Mathematics. This discourages results trigger the attention to improve this situation if the management of UPM wants to support the movement towards sustainable development.

\begin{tabular}{|c|c|}
\hline Sub-factor of Water and Energy Efficiency & $\begin{array}{c}\text { Total } \\
\text { desired } \\
\text { point }\end{array}$ \\
\hline 1.Water efficient landscaping. & \multirow{7}{*}{21} \\
\hline $\begin{array}{l}\text { 2. Water efficient landscaping no potable water } \\
\text { use. }\end{array}$ & \\
\hline 3.Innovative wastewater technologies. & \\
\hline $\begin{array}{l}\text { 4. Maximize water efficiency to reduce water } \\
\text { supply and wastewater systems. }\end{array}$ & \\
\hline 5.Building's energy-related systems are installed. & \\
\hline $\begin{array}{l}\text { 6.Establish the minimum level of energy } \\
\text { efficiency for the proposed building and } \\
\text { systems. }\end{array}$ & \\
\hline 7. Green Power. & \\
\hline
\end{tabular}

\section{E. Criteria of Materials and Resources}

Material and resources are very important in determining the ecological resource of building. In doing so, there are a few influential elements that need to be taken into account when the material and resources are selected (Table VI). The results of the application of the factor of materials and resources demonstrate that it is not encouraging as the highest point obtained for this particular factor is only five, compared to the total desired point of 12 . Even some buildings, low responding to this factor, namely the Faculty of Food Science and Biotechnology (Administrative and Academic building), Faculty of Human Ecology (Lecture Hall), the Faculty of
Agriculture (Department of Agriculture Technology) and the Faculty of Human Ecology (Department of Resource Management and Consumer Studies). The selection of materials and resources used in the construction of faculty buildings in UPM campus did not correspond to the concept of ecological design whereby the reusing and recycling processes were not employed at all.

\begin{tabular}{||c|c|}
\hline \multicolumn{3}{|c|}{ TABLE VI: MATERIALS AND RESOURCES } \\
\hline Sub-factor of Materials and Resources & $\begin{array}{c}\text { Total } \\
\text { desired } \\
\text { point }\end{array}$ \\
\cline { 1 - 2 } 1. Building reuse of existing walls, floors and roof. & \multirow{2}{*}{12} \\
\cline { 1 - 2 } 2. $\begin{array}{c}\text { Building reuse of interior non-structural } \\
\text { elements. }\end{array}$ & \\
\cline { 1 - 2 } 3. Redirect reusable materials to appropriate sites. & \\
\cline { 1 - 2 } 4. $\begin{array}{c}\text { Reuse building materials and products in order } \\
\text { to reduce demand for virgin materials and to } \\
\text { reduce waste. }\end{array}$ & \\
\hline
\end{tabular}

\section{F. Factor of Indoor Environmental Quality}

This factor determined the level of comfort in indoor spaces by applying building construction techniques that are more environmentally-friendly. For instance, the ventilation system and pollutant source control are installed to improve the indoor environmental quality. However, these types of systems require high-costly maintenance. Of the overall factors, this factor of indoor environmental quality held the highest points and many faculty buildings responded well to this factor (Table VII).

TABLE VII: INDOOR ENVIRONMENTAL QUALITY

\begin{tabular}{|c|c|}
\hline Sub-factor of indoor environmental quality & $\begin{array}{c}\text { Total } \\
\text { desired } \\
\text { point }\end{array}$ \\
\hline 1. Environmental Tobacco Smoke (ETS) Control & \multirow{6}{*}{24} \\
\hline $\begin{array}{l}\text { 2. Provide classrooms that are quiet and in which } \\
\text { teachers can speak to the class without } \\
\text { straining. }\end{array}$ & \\
\hline $\begin{array}{l}\text { 3. Provide capacity for ventilation system } \\
\text { monitoring to help sustain occupant comfort } \\
\text { and well-being. }\end{array}$ & \\
\hline $\begin{array}{l}\text { 4. Provide additional outdoor air ventilation to } \\
\text { improve indoor air quality. }\end{array}$ & \\
\hline $\begin{array}{l}\text { 5. Low-Emitting Materials: shall meet the testing } \\
\text { and product requirements (SIRIM) }\end{array}$ & \\
\hline 6. Indoor chemical \& pollutant source control. & \\
\hline
\end{tabular}

Results reveal that the highest point earned was 18 whereby two faculty buildings obtained this point: the faculty of Food Science and Biotechnology; and the Faculty of Postgraduate Studies. An observation made to the buildings indicated that most buildings have practiced this particular factor of ecological design in its design and it has made the indoor environment much conducive.

\section{G. Factor of Productivity, Comfort and Well-Being of Building Occupants}

Table VIII shows the sub-factor involved in the factor of productivity, comfort and well-being of building occupants. The factor of productivity, comfort and well-being, building occupants indicates that generally, the selected 23 buildings responded to it moderately. This factor is mainly about ensuring the level of comfort, of its occupants by installing environmental friendly design, such as increasing the 
ventilation system and applying the thermal comfort in designing the buildings.

TABLE VIII: The Productivity, COMForT AND WELL-BeING OF BUILDING OCCUPANTS

\begin{tabular}{|l|c|}
\hline $\begin{array}{c}\text { Sub-factor of the productivity, comfort and } \\
\text { well-being of building occupants }\end{array}$ & $\begin{array}{c}\text { Total } \\
\text { desired } \\
\text { point }\end{array}$ \\
\cline { 1 - 1 } 1. Lighting System Design \& Controllability: & \multirow{2}{*}{2} \\
\cline { 1 - 1 } 2. Thermal Comfort Controllability: & \multirow{2}{*}{24} \\
\cline { 1 - 1 } 3. Thermal Comfort Design & \\
\cline { 1 - 1 } 4. Daylight and views day-lighting. & \\
\hline 6. Finimum energy performance & \\
\cline { 1 - 1 } 7. Energy optimization & \\
\cline { 1 - 2 } 8. Increased ventilation &
\end{tabular}

Of the total desired point of 24, 12 buildings had more than $50 \%$ of the achievable target. This makes that nearly half of the selected buildings responded moderately to this factor. The buildings of the Faculty of Human Ecology (Department of Resource Management and Consumer Studies) and the faculty of Administrative and Business Building obtained the highest point, reflecting the these buildings had the most conducive level among the 23 selected buildings.

\section{CONCLUSION}

This project paper discussed the issue of the compliance of ED on buildings in UPM Serdang campus. It responded to the issue of the limited consideration given by the building designer and decision-maker to the concept of ecological design in Malaysia as a whole by undertaking an observation study covering the significant factors involved in ecological design in 23 selected buildings in UPM Serdang campus. This research has successfully responded to the issue of the limited consideration given by the building designer and decision-maker to the concept of ED in Malaysia as a whole by undertaking an observation study covering the significant variables involved in the ED in 23 selected buildings in the study area.

\section{REFERENCES}

[1] P. Terri, "Experimental green strategies: redefining ecological design research," Architectural Design, vol. 81, issue 6, pp. 14-19, 2011.

[2] G.-M. Dominique, Sustainable Architecture and Urbanism: Concepts, Technologies, Examples, Birkhäuser, Switzerland, 2002.

[3] M. H. A. Samad, A. M. A. Rahman, and W. M. W. Harun, "The awareness and role of building professionals towards green developments," in Proc. International Conference on Environmental Design, Gombak, Selangor, 17-19 July, 2008.

[4] V. der Ryn et al., Ecological Design, Washington: Island Press, 1996.

[5] S.James, Ecological Architecture: A Critical History, London: Thames and Hudson Limited, 2005.

[6] S. James, Sustainable Architecture: Principles, Paradigm, and Case Studies, New York: McGraw-Hil, 19971.

[7] Y. Ken, Designing with Nature: the Ecological Basis for Architectural Design, New York: McGraw-Hill, Inc, 1995.

[8] Y. Ken, Ecodesign: A Manual for Ecological Design, Great Britain: Wiley-Academy, 2006.

[9] Y. Simos, "Adaptive strategies for an ecological architecture," Architectural Design, vol. 81, issue 6, pp. 62-69, 2011.

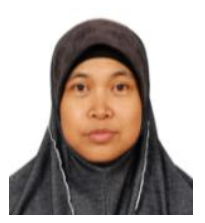

M. Zainora Asmawi was born in 1970 in Kuala Lumpur, Malaysia. She obtained her bachelor degree in the field of urban and regional planning from Technology University of Malaysia in 1993. She has a master degree of environment from Putra University of Malaysia in 2000 and she pursued her PhD degree in coastal planning and management from the University of Portsmouth, United Kingdom in 2006. She has produced several publications including: Land use planning: A case study of LUAS, Malaysia, APCBEE Procedia, vol. 1, pp. 325-330, 2012 and Application of GIS-planning decision support system in predicting development impact assessment, International Archives of the Photogrammetry, Remote Sensing and Spatial Information Sciences, vol. XXXVIII-4/C211, pp. 51-56, 2011. Her book entitled 'Integrated coastal management and town planning in Peninsular Malaysia: Concept and practice' published by VDM \& Co. in the USA (ISBN 978-3-639-26775-4). Dr Asmawi is a corporate town planner, registered with the Malaysian Institute of Planners (MIP) and Board of Town Planners, Malaysia. At a local level, her research work has won a gold medal in the IIUM Research Invention, Innovation and Exhibition (IRIIE) 2011.

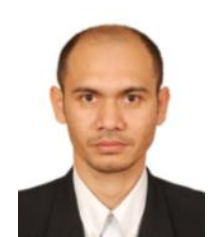

Abdul Razak Abd Aziz was born in Johor, Malaysia in 1973. He holds a bachelor degree in architecture from the Technology University of Malaysia in 2001 and a master degree of environment from Putra University of Malaysia in 2010. Mr. Aziz is registered with the Malaysian Institute of Architect, who is currently working as an architect with vast experience in designing and involving in constructing green buildings in Malaysia. 